\title{
PREFACE AND ACKNOWLEDGMENTS
}

It will quickly become clear to any reader of this book that my approach is often colored by a consciousness of the history of South African wine. The title, of course, suggests that the focus is on one particular slice of history-the most recent-but that is so only insofar as I am always aware of the past informing the present of the new South African wine industry. This is, after all, one of the oldest wine industries of the so-called New World, and the only one that, with the wines of Constantia, made a notable contribution to the greatness of wine before the twentieth century. The notorious politics and social structures of the past still have less-attractive echoes today, but I have effectively defined the "newness" that is my focus with a date that most immediately has a sociohistorical significance: 1994, the year of the country's first nonracial parliamentary election. That was, of course, the event that allowed the reentry of Cape wine into the world markets, after many years of boycott and isolation, and precipitated the vinous revolution that rolls on yet. The wine lands are redolent of the recent and the older past, which are inevitably embedded in the change and growth of the past few decades. I look forward to there being one day a comprehensive and readily available history of South African wine; meanwhile, in a thoroughly unspecialist way and in a general book, I offer here what little I can of it, as part of an attempt to characterize and account for the present.

I do not venture the wineries profiled as a definitive list of the best producers of South African wine; to do so would make me even more vulnerable to criticism than I will be in claiming these as among the best. (Other interesting wineries are also mentioned in the introductions to the various regions.) Many are an ineluctable choice, of course, but there were sometimes competing claims to be weighed, in the context of space limitations. 
Perhaps the category of producers that is most egregiously missing is that of garagistes (some of them the personal labels of winemakers at larger properties), and that is because many of them might and do make fine wine but in tiny quantities and with little breadth of distribution. Some of them have perforce given way here to larger, more "significant" wineries whose wines I might personally value a little less, or even to producers whose greatest claim is sentimental, because of past prestige or a long history. A further consideration: lexicographer Samuel Johnson wrote, "No dictionary of a living tongue ever can be perfect, since, while it is hastening to publication, some words are budding"; books about wineries and wines are similarly doomed. Because of the way the South African wine industry has changed over the past few decades and is continuing to change (though now at a slower rate, perhaps), these winery profiles are something like a photograph of a moving object, and that has its implications for coverage of both the broader picture and the details. That all said, I can't evade the fact that my own taste (and probably my own imperfect information and experience) inevitably prompted some inclusions and omissions. In brief-I am aware that some good producers are probably neglected. It should be noted that the maps that accompany the chapters devoted to the different areas indicate only the wineries that are mentioned in the text-approximately a quarter of the total.

The wine world I know in South Africa is a gregarious, sharing, discussing one, so that the views and judgments in this book always owe something to others, as do whatever information and understanding I have picked up. Nonetheless, any errors are mine and when they are pointed out I will have to refer to Dr. Johnson once more and say, as he reportedly did when asked how he could possibly have made a particular mistake in his dictionary: "ignorance, Madam, pure ignorance." So: thanks to winemakers and viticulturists, to fellow wine journalists, to those with whom I often drink wine and talk and argue happily about it. More specific thanks to friends and colleagues who've encouraged this project, who've read parts of it and given opinions and advice: Angela Lloyd (who was particularly helpful with some of the winery profiles), also Michael Fridjhon, Melvyn Minnaar, John Platter, Mark Solms, Cathy van Zyl, and Philip van Zyl. And thanks to Blake Edgar of University of California Press for many useful observations. Those who, like me, gleefully seek out statistics in South Africa are fortunate that SAWIS (South African Wine Industry Information and Statistics) is in one respect an old-fashioned institution as well as being a formidably efficient one-it believes that its function is to assist inquirers, and Yvette van der Merwe and her colleagues have been unstintingly helpful. André Matthee of the Wine and Spirit Board has been similarly obliging with matters of regulation and law.

Some scattered sentences in this book have appeared on my Web site, and a few in the pages of that excellent journal The World of Fine Wine, to whose publisher and editor I am grateful for allowing me to recycle my words. 